\title{
Feeding ecology of three amphipod species Synchelidium lenorostralum, S. trioostegitum and Gitanopsis japonica in the surf zone of a sandy shore
}

\author{
Ok Hwan $\mathrm{Yu}^{1, *}$, Hae-Lip $\mathrm{Suh}^{2}$, Yoshihisa Shirayama ${ }^{1}$ \\ ${ }^{1}$ Seto Marine Biological Laboratory, Kyoto University, 459 Shirahama, Wakayama 649-2211, Japan \\ ${ }^{2}$ Department of Earth Systems and Environmental Sciences, Chonnam National University, 300 Yongbong-dong, \\ Gwangju 500-757, Republic of Korea
}

\begin{abstract}
The influence of seasonal and ontogenetic changes on the dietary composition of 3 amphipod species (Synchelidium lenorostralum, S. trioostegitum and Gitanopsis japonica) were studied in the surf zone of a sandy shore habitat in Dolsando, southern Korea. The 2 species of Synchelidium were found to be carnivorous feeders, consuming mainly benthic harpacticoid copepods, whereas $G$. japonica had a diet consisting of both copepods and detritus. The dietary composition of S. lenorostralum and $S$. trioostegitum overlapped for all ontogenetic stages. Little overlap was found in the dietary composition of $G$. japonica compared with the 2 Synchelidium species, a characteristic that might favor the co-existence of the 3 species. $S$. lenorostralum displayed significant differences in dietary composition between sexes, among developmental stages, and over the seasonal cycle. For $S$. trioostegitum, dietary composition varied over the seasonal cycle. Juveniles of Synchelidium fed mainly on copepod nauplii and nematodes as well as on benthic harpacticoid copepods. Our results suggest that the biological interactions between benthic amphipods and meiofauna, such as benthic harpacticoid copepods and nematodes, may be important in the trophic chain of sandy shore surf zone habitats.
\end{abstract}

KEY WORDS: Synchelidium lenorostralum · S. trioostegitum • Gitanopsis japonica · Amphipoda · Feeding $\cdot$ Sandy surf zone

\section{INTRODUCTION}

Sandy shore surf zones comprise a significant area of coastal marine habitats (Ross et al. 1987, Brown \& McLachlan 1990). Water circulation in the surf zone concentrates particulate foods such as detritus, planktonic microalgae and/or benthic microalgae. The biomass of zooplankton, which feed on particulate food, is known to be high in the surf zone and to decrease with distance from the shore. In addition, food chains in beach environments are known to be centered in the surf zone rather than in the intertidal zone (Ross et al. 1987).

The macrofauna of sandy beaches is often abundant and in some cases can reach exceptionally high den- sities (see review by McLachlan 1983). Macrofauna occupy a middle role in the food chain; they process food from the surf zone and in turn, are consumed by top predators such as birds and fish (McLachlan 1983). Several studies have reported that intertidal macrofauna constitute a major part of the diet of surf zone fishes (Ross et al. 1987, Ojeda \& Dearborn 1991, Edgar \& Shaw 1995, De Troch et al. 1998, Harvey 1998, Takahashi et al. 1999). However, there is little published information on the interactions between macrofauna and their prey in sandy beach habitats (McLachlan 1983, Brown \& McLachlan 1990).

Amphipods are widespread throughout a diverse range of tropical, temperate and arctic intertidal 
sandy shore habitats, often dominating benthic macrofaunal communities in terms of both numbers and biomass (Fenchel et al. 1975, Wijnsma et al. 1999, Dittmann 2000). Moreover, amphipods are considered to be one of the most important secondary producers (Carrasco \& Arcos 1984) and a major food source for a variety of marine predators (Kline \& Wood 1996, Schlacher \& Wooldridge 1996, Beare \& Moore 1997, MacNeil et al. 1999, Takahashi et al. 1999). Amphipods play an important role in surf zone food webs, acting as a trophic link from primary producers to higher-order consumers. Clearly, quantitative assessments of trophic relationships between amphipods and their prey/predators are important for our understanding of energy flow in sandy shore surf zone environments (Gerdol \& Hughes 1994).

Various aspects of amphipod feeding activity have been studied, including diet (Fenchel et al. 1975, Biernbaum 1979, Nielsen \& Kofoed 1982, Icely \& Nott 1985, Stuart et al. 1985), diel feeding patterns (SainteMarie 1986, Gerdol \& Hughes 1994, Ingolfsson \& Agnarsson 1999) and the influence of food quality on growth and reproduction (Gee 1988, Johnson \& Wiederholm 1989, Delong et al. 1993, Pöckl 1995, Poltermann 2000). These studies have provided basic information on the feeding ecology of freshwater and marine amphipods inhabiting sublittoral and intertidal habitats. However, there is no information available on the feeding characteristics of amphipods in sandy shore surf zone habitats.

In the sandy shore surf zone of Dolsando, southern Korea, Synchelidium lenorostralum, S. trioostegitum and Gitanopsis japonica are the dominant amphipod species. These amphipods occupy the lower part of the water column from a depth of $1 \mathrm{~m}$ (measured at low water during the spring tide) and do not exhibit seasonal or diel migration (Yu 2001). S. lenorostralum is known to feed mainly upon benthic harpacticoid copepods, suggesting an important role in biological interactions of the sandy shore surf zone (Yu et al. 2002b). Despite their abundance and potentially important contribution to food webs of sandy shore surf zone habitats, there is no information on the feeding characteristics of different species or different ontogenetic stages within species.

The aim of this study is to determine the dietary composition as well as seasonal and ontogenetic variations in the diet of 3 amphipod species, Synchelidium lenorostralum, S. trioostegitum and Gitanopsis japonica, in the surf zone of a sandy shore habitat. The results reported here contribute to our understanding of amphipod feeding strategies, life history characteristics and the role of amphipods in sandy shore surf zone ecosystem processes.

\section{MATERIALS AND METHODS}

Benthic amphipods were collected monthly between July 1996 and June 1997 from a depth of $1 \mathrm{~m}$ at the low water mark of the spring tide in Dolsando (34 $37^{\circ} 39^{\prime \prime} \mathrm{N}$, $\left.127^{\circ} 47^{\prime} 44^{\prime \prime} \mathrm{E}\right)$, southern Korea. The area is moderately sheltered and on average, particle sizes are composed of $66 \%$ fine and $26 \%$ medium sand. The beach slope at the sampling site is $1: 48$ and the width of the intertidal zone is $150 \mathrm{~m}$. The spring tidal range at the study site is approximately $5 \mathrm{~m}$. Detailed descriptions of the environmental characteristics at the sampling site are reported in Yu et al. (2002a,b).

Parallel to the shoreline, 5 samples were taken using a sledge net (mouth size: $12 \times 30 \mathrm{~cm}$; mesh size: $0.3 \mathrm{~mm}$ ) over a distance of $20 \mathrm{~m}$ and at a speed of approximately $1 \mathrm{~m} \mathrm{~s}^{-1}$. The sledge with a thick chain at the bottom leading edge was drawn across the substratum on 2 lateral skids. The sledge skimmed the surface at a depth of approximately $1 \mathrm{~cm}$. Concentrated tow samples were immediately preserved in 5\% buffered formalin in seawater.

Amphipods collected during each monthly sampling were divided into 4 categories: juveniles, males, nonovigerous females and ovigerous females (see Donn \& Croker 1986 for a detailed description). The gut of each amphipod was carefully removed and immersed in glycerol on a glass slide. The gut contents were examined under a differential interference microscope (Zeiss Axioskop) and a cold-field emission scanning electron microscope (Hitachi S-4700) for identification to the lowest possible taxonomic category. Prior to observation by SEM, the gut contents were dehydrated using a graded ethanol and $t$-butyl alcohol series and then freeze dried. Samples were mounted on stubs and sputter coated with platinum. The dietary composition was determined for each of the ontogenetic categories of all 3 amphipod species monthly.

Dietary composition was analyzed using the point method (Wear \& Haddon 1987). This method is suitable for assessing the diets of crustaceans whose gut contents are macerated and difficult to quantify (Takahashi \& Kawaguchi 1998, Oh et al. 2001). The gut fullness was estimated on a subjective 6 -step scale from 0 to 1 as follows: a score of 0 was given for an empty gut; 0.02 for $5 \%$ full or only remnants; 0.25 for $25 \%$ full $(<35$ and $>5 \%) ; 0.5$ for $50 \%$ full $(<65$ and $>35 \%) ; 0.75$ for $75 \%$ full $(<100$ and $>65 \%)$; and 1 for a $100 \%$ full gut. The relative contribution of each food item to the total gut content was subjectively assessed on a 5-step scale: 0 points for an item not found in the gut; 2.5 points if an item occupied less than $5 \%$ or only remnants; 25 points for $25 \%(<35$ and $>5 \%), 25$ points; 50 points for $50 \%(<65$ and $>35 \%) ; 75$ points for $75 \%$ $(<100$ and $>65 \%)$; and 100 points for an item repre- 
senting 95 to $100 \%$ of gut contents. The relative contribution of each food item was then weighted by multiplying it by the estimated value for gut fullness. The number of points obtained by each food item was expressed as a percentage of the total gut content. The frequency of occurrence $(F)$ and relative abundance (A) for each food type was estimated using the following equations:

$$
\begin{gathered}
\% F=\left(\mathrm{n}_{i} / N\right) \times 100 \\
\% A=\left(\Sigma \mathrm{S}_{i} / \Sigma \mathrm{S}_{t}\right) \times 100
\end{gathered}
$$

where $\mathrm{n}_{i}$ is the number of amphipods with food $i$ in the gut, $N$ is the total number of amphipods with gut contents, $\mathrm{S}_{i}$ the number of food $i$ and $\mathrm{S}_{t}$ the total number of food items.

Based on the composition of the gut contents, an overlap index of diets was calculated (both intra- and interspecifically) using the following equation (Schoener 1970):

$$
R o=100\left(1-1 / 2 \sum\left|p x_{i}-p y_{i}\right|\right)
$$

where $R o$ is the overlap index expressed as a percentage, and $p x_{i}$ and $p y_{i}$ are the relative proportions of each food item $i$ obtained for the $x$ th and yth species.

Prior to statistical analyses, data were tested for homogeneity of variances and normality using Bartlett's test (Statistica version 5.1, Statsoft, 1984-1996). Normally distributed data were tested with parametric methods; otherwise, non-parametric methods were used. The Kruskal-Wallis and Friedman tests were used to examine differences in the abundance of food items between sampling months and between the 4 ontogenetic categories (MINITAB version 12.1, Minitab, 1998). The differences in gut content composition between categories was examined using the $\chi^{2}$ test.

\section{RESULTS}

\section{Synchelidium lenorostralum Hirayama 1986 (Oedicerotidae)}

The most common food items in the gut of Synchelidium lenorostralum were found to be harpacticoid copepods (mainly Robertgurneya sp.), which occurred in over $80 \%$ of the guts examined and constituted more than $75 \%$ of total gut content (Fig. 1A). The other categories contributed only minor proportions to the $\operatorname{diet}(<10 \%$ of total abundance each).

Harpacticoid copepods were the dominant species found in the guts of all 4 ontogenetic categories (Table 1). Nematodes, crustacean fragments and copepod nauplii (mainly the nauplius I stage of harpacticoid copepods) represented from 5.4 to $6.4 \%$ of total gut contents in males. These food items
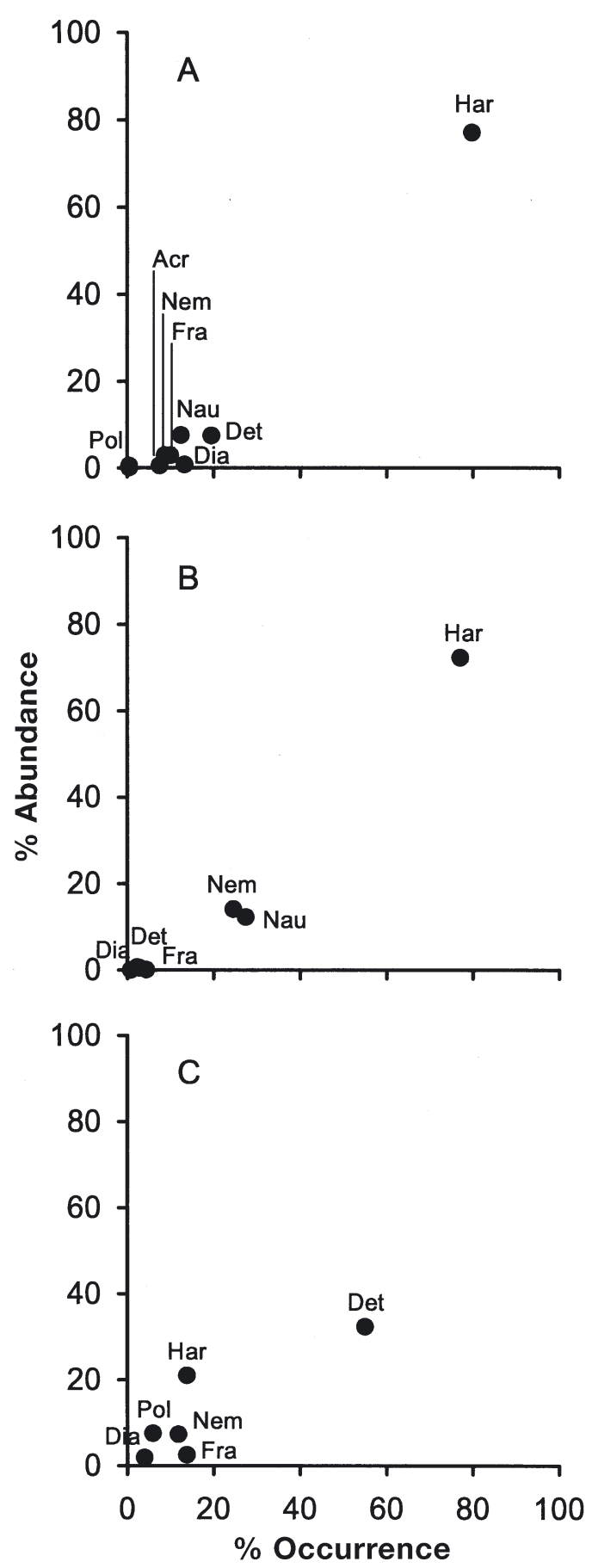

Fig. 1. Overall diet. Food items abundance plotted against frequency of occurrence of food item for (A) Synchelidium lenorostralum, (B) S. trioostegitum and (C) Gitanopsis japonica. Values are calculated for pooled samples irrespective of months and categories. Har: harpacticoid copepods; Nem: Nematodes; Acr: Acartia copepod species; Frg: crustacean fragments; Nau: copepod nauplii; Pol: Polychaetes; Dia: Diatoms; Det: detritus

occurred in very low abundance in the guts of nonovigerous and ovigerous females. In juveniles, copepod nauplii and detritus represented more than $10 \%$ 
Table 1. Synchelidium lenorostralum. Diet compositions in each ontogenetic category. \% A: percentage of abundance; \% F: frequency of occurrence; $\mathrm{n}$ : number of specimens examined

\begin{tabular}{|c|c|c|c|c|c|c|c|c|}
\hline \multirow{2}{*}{ Food items } & \multicolumn{2}{|c|}{ Juvenile ( $\mathrm{n}=81$ ) } & \multicolumn{2}{|c|}{ Male (n = 62) } & \multicolumn{2}{|c|}{ Female $(\mathrm{n}=51)$} & \multicolumn{2}{|c|}{ Ovigerous female $(\mathrm{n}=48)$} \\
\hline & $\% A$ & $\% F$ & $\% A$ & $\% F$ & $\% A$ & $\% F$ & $\% A$ & $\% F$ \\
\hline Harpacticoid copepods & 64.3 & 63.0 & 76.4 & 80.6 & 89.6 & 94.1 & 89.0 & 91.7 \\
\hline Nematodes & 2.7 & 7.4 & 6.4 & 12.9 & 1.0 & 9.8 & 0.6 & 4.2 \\
\hline Acartia sp. & 0.0 & 0.0 & 0.0 & 0.0 & 0.0 & 0.0 & 3.3 & 2.1 \\
\hline Crustacean fragments & 3.5 & 11.1 & 5.5 & 16.1 & 0.0 & 0.0 & 1.5 & 10.4 \\
\hline Copepod nauplii & 15.6 & 19.8 & 5.4 & 14.5 & 2.5 & 7.8 & 0.5 & 2.1 \\
\hline Polychaetes juveniles & 0.0 & 0.0 & 0.0 & 0.0 & 0.4 & 2.0 & 0.0 & 0.0 \\
\hline Gyrosigma sp. & 0.5 & 6.2 & 1.0 & 16.1 & 0.9 & 13.7 & 1.1 & 20.8 \\
\hline Detritus & 12.6 & 25.9 & 5.0 & 22.6 & 4.8 & 9.8 & 4.0 & 14.6 \\
\hline Sand & 0.8 & 12.3 & 0.3 & 8.1 & 0.8 & 5.9 & 0.0 & 0.0 \\
\hline
\end{tabular}

Table 2. Synchelidium lenorostralum. Contingency table analysis of 5 different categories of food items in each ontogenetic category. Values are the total number of food items with expected values in parentheses. $\chi^{2}$ and $G$-statistics are significant ( $\left.{ }^{* *} p<0.01\right)$

\begin{tabular}{|c|c|c|c|c|c|c|c|}
\hline Food items & Juvenile & Male & Female & Ovigerous female & $N_{i}$ & $\chi^{2}$ & $G_{i}$ \\
\hline Harpacticoids & $51(60)$ & $50(56)$ & $48(38)$ & $44(39)$ & 193 & 5.13 & 5.01 \\
\hline Nematodes & $6(7)$ & $8(6)$ & $5(4)$ & $2(4)$ & 21 & 1.98 & 2.22 \\
\hline Crustaceans & $25(17)$ & 19 (16) & $4(11)$ & $7(11)$ & 55 & 10.13 & 11.27 \\
\hline Diatoms & $5(10)$ & $10(9)$ & $7(6)$ & $10(6)$ & 32 & 4.54 & 4.80 \\
\hline Detritus & 21 (15) & $14(14)$ & $5(9)$ & $7(10)$ & 47 & 5.47 & 5.60 \\
\hline$N_{i}$ & 108 & 101 & 69 & 70 & 348 & & \\
\hline$\chi^{2}$ & 10.32 & 1.18 & 9.09 & 5.96 & & $27.25^{* *}$ & \\
\hline$G_{i}$ & 10.11 & 1.84 & 10.72 & 6.23 & & & $28.90^{* *}$ \\
\hline
\end{tabular}

of total gut contents. There were significant differences in gut content composition between the 4 ontogenetic categories (Table 2). A statistically significant difference $\left(\chi^{2}=9.63\right.$, df $\left.=4, p<0.05\right)$ in gut content composition was found between males and females. Among the range of food items, the main source of variation was crustaceans $\left(\chi^{2}=10.13\right)$, consisting mainly of crustacean fragments and copepod nauplii. Among the 4 ontogenetic categories, the main source of variation was juveniles $\left(\chi^{2}=10.32\right)$. The overlap index of gut content composition between juveniles and males was $82 \%$. The indices obtained between juveniles and non-ovigerous females and between juveniles and ovigerous females were less than those for males (Table 3). However, the overlap indices between males and non-ovigerous females and between non-ovigerous and ovigerous females were 93 and $95 \%$, respectively.

There was a significant difference between month and dietary composition of Synchelidium lenorostralum (Friedman test: $S=33.47$, df $=6, \mathrm{p}<$ 0.001). During the winter months, harpacticoid copepods accounted for more than $95 \%$ of the diet in $\% A$ and
\% F. However, in August and September, this fraction dropped to $40 \%$ and coincided with an increase in the amount of detritus, which accounted for more than $39 \%$ of abundance and $60 \%$ of occurrence (Table 4 ). The monthly variation in the proportion of harpacticoid copepods in the gut contents was statistically significant (Kruskal-Wallis test: $H=76.91$, df $=11, \mathrm{p}<0.001$ ). Copepod nauplii were detected in the gut contents only in November, April and May, contributing more than $40 \%$ to total gut contents with respect to both \% $A$ and $\% F$ in April.

There was a statistically significant variation in dietary composition throughout the year (for food

Table 3. Intraspecific overlap indices of diets in Synchelidium lenorostralum, $S$. trioostegitum and Gitanopsis japonica using the Schoener overlap index $(R o)$ and Spearman rank correlation $\left(\mathrm{R}_{\mathrm{S}}\right)$ (in parentheses). ${ }^{*} \mathrm{p}<0.05,{ }^{* *} \mathrm{p}<0.01$, ${ }^{* * *} \mathrm{p}<0.001 ;-$ : no data

\begin{tabular}{|llll|}
\hline Ontogenetic category & S. lenorostralum & S. trioostegitum & G. japonica \\
\hline Juvenile vs Male & $82\left(0.832^{* *}\right)$ & $76\left(0.935^{* * *}\right)$ & - \\
Juvenile vs Female & $74\left(0.752^{*}\right)$ & $86\left(0.865^{* *}\right)$ & - \\
Juvenile vs Ovigerous female & $72(0.432)$ & $90\left(0.811^{*}\right)$ & - \\
Male vs Female & $93(0.592)$ & $93\left(0.778^{*}\right)$ & $90\left(0.766^{*}\right)$ \\
Male vs Ovigerous female & $84(0.424)$ & $79\left(0.778^{*}\right)$ & $67(0.323)$ \\
Female vs Ovigerous female & $95(0.336)$ & $91\left(0.964^{* * *}\right)$ & $74(0.428)$ \\
\hline
\end{tabular}


Table 4. Synchelidium lenorostralum. Monthly variation of food items. \% A: percentage of abundance; \% F: frequency of occurrence; n: number of specimens examined

\begin{tabular}{|c|c|c|c|c|c|c|c|c|c|c|c|c|c|c|c|c|c|c|c|}
\hline \multirow[t]{2}{*}{ Month } & \multirow[t]{2}{*}{$\mathrm{n}$} & \multicolumn{2}{|c|}{$\begin{array}{c}\text { Harpacticoid } \\
\text { copepods }\end{array}$} & \multicolumn{2}{|c|}{ Nematodes } & \multicolumn{2}{|c|}{ Acartia sp. } & \multicolumn{2}{|c|}{$\begin{array}{l}\text { Crustacean } \\
\text { fragments }\end{array}$} & \multicolumn{2}{|c|}{$\begin{array}{l}\text { Copepod } \\
\text { nauplii }\end{array}$} & \multicolumn{2}{|c|}{ Polychaetes } & \multicolumn{2}{|c|}{ Gyrosigma sp. } & \multicolumn{2}{|c|}{ Detritus } & \multicolumn{2}{|c|}{ Sand } \\
\hline & & $\% A$ & $\% F$ & $\% A$ & $\% F$ & $\% A$ & $\% F$ & $\% A$ & $\% F$ & $\% A$ & $\% F$ & $\% A$ & $\% F$ & $\% A$ & $\% F$ & $\% A$ & $\% F$ & $\% A$ & $\% F$ \\
\hline \multicolumn{20}{|l|}{1996} \\
\hline Jul & 4 & 77.8 & 50.0 & 2.2 & 50.0 & 0.0 & 0.0 & 7.2 & 50.0 & 0.0 & 0.0 & 0.0 & 0.0 & 0.6 & 25.0 & 6.1 & 50.0 & 6.1 & 50.0 \\
\hline Aug & 19 & 31.3 & 31.6 & 7.4 & 21.1 & 0.0 & 0.0 & 9.2 & 26.3 & 0.0 & 0.0 & 0.0 & 0.0 & 0.2 & 5.3 & 49.2 & 73.7 & 2.7 & 15.8 \\
\hline Sep & 13 & 26.7 & 30.8 & 20.0 & 15.4 & 0.0 & 0.0 & 13.6 & 38.5 & 0.0 & 0.0 & 0.0 & 0.0 & 0.0 & 0.0 & 39.2 & 61.5 & 0.4 & 23.1 \\
\hline Oct & 23 & 87.1 & 91.3 & 1.4 & 4.3 & 0.0 & 0.0 & 7.1 & 8.7 & 0.0 & 0.0 & 0.0 & 0.0 & 0.2 & 8.7 & 3.7 & 26.1 & 0.4 & 13.0 \\
\hline Nov & 36 & 77.7 & 72.2 & 2.3 & 2.8 & 0.0 & 0.0 & 0.0 & 0.0 & 18.9 & 27.8 & 0.0 & 0.0 & 0.9 & 2.8 & 0.2 & 11.1 & 0.0 & 0.0 \\
\hline Dec & 26 & 95.3 & 92.3 & 1.3 & 3.8 & 0.0 & 0.0 & 2.0 & 7.7 & 0.0 & 0.0 & 0.0 & 0.0 & 0.0 & 0.0 & 1.3 & 7.7 & 0.1 & 3.8 \\
\hline \multicolumn{20}{|l|}{1997} \\
\hline Jan & 12 & 96.7 & 100.0 & 1.7 & 8.3 & 0.0 & 0.0 & 0.0 & 0.0 & 0.0 & 0.0 & 0.0 & 0.0 & 1.5 & 50.0 & 0.0 & 0.0 & 0.1 & 8.3 \\
\hline Feb & 15 & 99.8 & 100.0 & 0.0 & 0.0 & 0.0 & 0.0 & 0.0 & 0.0 & 0.0 & 0.0 & 0.0 & 0.0 & 0.2 & 6.7 & 0.0 & 0.0 & 0.0 & 0.0 \\
\hline Mar & 27 & 85.8 & 96.3 & 1.8 & 11.1 & 0.0 & 0.0 & 4.0 & 14.8 & 0.0 & 0.0 & 1.1 & 3.7 & 4.7 & 59.3 & 2.3 & 7.4 & 0.3 & 7.4 \\
\hline Apr & 29 & 48.9 & 75.9 & 0.2 & 6.9 & 0.0 & 0.0 & 2.2 & 10.3 & 42.7 & 58.6 & 0.0 & 0.0 & 0.0 & 0.0 & 4.1 & 17.2 & 1.8 & 6.9 \\
\hline May & 27 & 90.8 & 96.3 & 1.5 & 7.4 & 4.1 & 3.7 & 0.1 & 3.7 & 3.1 & 11.1 & 0.0 & 0.0 & 0.1 & 7.4 & 0.3 & 3.7 & 0.0 & 0.0 \\
\hline Jun & 11 & 82.0 & 81.8 & 4.8 & 18.2 & 0.0 & 0.0 & 0.0 & 0.0 & 0.0 & 0.0 & 0.0 & 0.0 & 2.4 & 18.2 & 10.7 & 27.3 & 0.1 & 9.1 \\
\hline
\end{tabular}

items contributing $>3 \%$ to total abundance) for different developmental stages of Synchelidium lenorostralum (Table 9). In juveniles, the dietary composition varied with month. In the summer (July to September), detritus accounted for over $50 \%$ of total gut content abundance, whereas harpacticoid copepods dominated gut contents in the winter (Fig. 2 ). The proportion of copepod nauplii in the gut contents showed 2 peaks, in November and April. In males, harpacticoid copepods were more common in the gut contents from November to March. During the summer, this proportion decreased and coincided with a proportional increase in the contribution from detritus and nematodes. In April, copepod nauplii accounted for over $50 \%$ of total gut contents. For non-ovigerous and ovigerous females, harpacticoid copepods were the most abundant component in the gut throughout the year. Some variation in the dietary composition of non-ovigerous and ovigerous females was also observed throughout the year (Table 9).

\section{Synchelidium trioostegitum Jo 1990 (Oedicerotidae)}

The most common food item found in the gut of Synchelidium trioostegitum was harpacticoid copepods (mainly Robertgurneya sp.), which occurred in over $75 \%$ of the guts examined and constituted more than $70 \%$ of total gut contents (Fig. 1B). Nematodes and copepod nauplii (mainly nauplius I stage of harpacticoid copepods) were the second major contributors to the diet. The other categories contributed only minor amounts to the diet $(<10 \%$ of total abundance each).

Harpacticoid copepods were the dominant species in the guts of all 4 ontogenetic categories (Table 5). Copepod nauplii constituted $13.5 \%$ of the total abundance of food items in the guts of males, but occurred in a very low proportion in the guts of females. Nematodes represented more than $18 \%$ of total abundance in both non-ovigerous and ovigerous females. In juveniles, nematodes and copepod nauplii constituted over $18 \%$ of total gut contents. There was no significant difference in gut contents between the 4 ontogenetic categories $\left(\chi^{2}=11.47, \mathrm{df}=6, \mathrm{p}>0.05\right)$. A high dietary overlap index was found between males and females. The lowest dietary overlap index was found between juveniles and males (Table 3). The Spearman rank coefficients were significant in all cases, indicating a high degree of similarity in diet between different ontogenetic stages.

There was a significant difference between months in the dietary composition of Synchelidium trioostegitum (Friedman test: $S=39.56$, df $=5$, p < 0.001). During winter, harpacticoid copepods accounted for over $70 \%$ of the diet for both $\% A$ and $\% F$; however, in November and April, the proportion dropped to $50 \%$ (Kruskal-Wallis test: $H=23.13$, df $=10, \mathrm{p}<0.01$ ). This change coincided with an increase in the contribution of nematodes and copepod nauplii, which accounted for more than 30 and $40 \%$ of gut content abundance, respectively (Table 6). Nematodes accounted for over $20 \%$ of total gut contents from September to December, whereas copepod nauplii accounted for more than $35 \%$ of the diet in $\% A$ and $\% F$ in November and April. 
Table 5. Synchelidium trioostegitum. Diet compositions in each ontogenetic category. \% A: percentage of abundance, \% F: frequency of occurrence; $\mathrm{n}$ : number of specimens examined

\begin{tabular}{|c|c|c|c|c|c|c|c|c|}
\hline \multirow[t]{2}{*}{ Food items } & \multicolumn{2}{|c|}{ Juvenile ( $\mathrm{n}=38)$} & \multicolumn{2}{|c|}{ Male $(\mathrm{n}=35)$} & \multirow{2}{*}{$\begin{array}{c}\text { Female }(\mathrm{n}=39) \\
\% A\end{array}$} & \multicolumn{3}{|c|}{ Ovigerous female $(\mathrm{n}=27)$} \\
\hline & $\% A$ & $\% F$ & $\% A$ & $\% F$ & & $\% F$ & $\% A$ & $\% F$ \\
\hline Harpacticoid copepods & 62.1 & 65.8 & 85.6 & 88.6 & 73.8 & 79.5 & 66.4 & 74.1 \\
\hline Nematodes & 19.0 & 26.3 & 0.8 & 2.9 & 18.3 & 38.5 & 18.9 & 29.6 \\
\hline Crustacean fragments & 0.0 & 0.0 & 0.0 & 0.0 & 0.5 & 2.6 & 2.2 & 11.1 \\
\hline Copepod nauplii & 18.8 & 31.6 & 13.5 & 28.6 & 5.3 & 23.1 & 11.8 & 25.9 \\
\hline Hyalodiscus sp. & 0.0 & 0.0 & 0.0 & 0.0 & 0.0 & 0.0 & 0.1 & 3.7 \\
\hline Detritus & 0.0 & 2.6 & 0.0 & 0.0 & 2.0 & 2.6 & 0.4 & 3.7 \\
\hline Sand & 0.1 & 2.6 & 0.1 & 5.7 & 0.1 & 2.6 & 0.2 & 7.4 \\
\hline
\end{tabular}
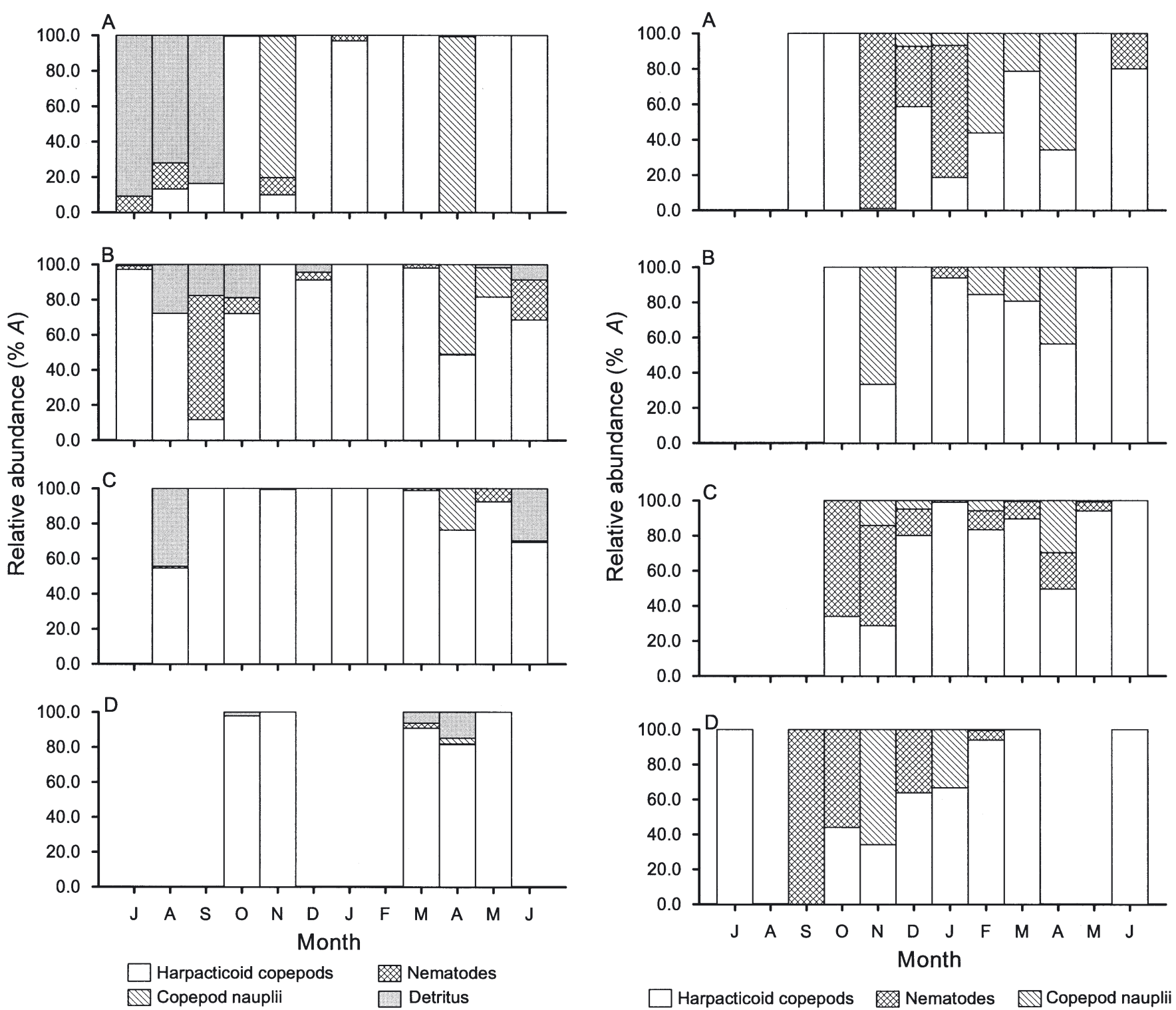

Fig. 2. Monthly relative abundance $(\% A)$ of harpacticoid copepods, nematodes, copepod nauplii and detritus consumed by Synchelidium lenorostralum. (A) Juveniles, (B) males, (C) females, (D) ovigerous females

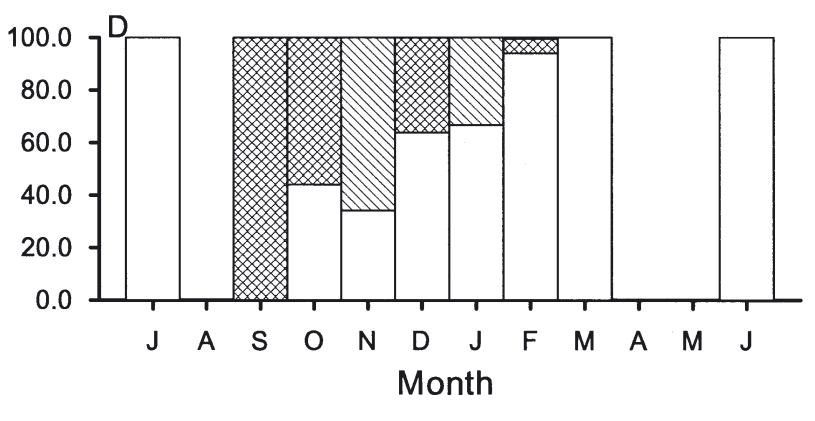

Harpacticoid copepods Nematodes $\mathbb{Q}$ Copepod nauplii

Fig. 3. Monthly relative abundance $(\% A)$ of harpacticoid copepods, nematodes and copepod nauplii consumed by Synchelidium trioostegitum. (A) Juveniles, (B) males, (C) females,

(D) ovigerous females 
Table 6. Synchelidium trioostegitum. Monthly variation of food items \% A: percentage of abundance; \% F: frequency of occurrence; n: number of specimens examined; -: no data

\begin{tabular}{|c|c|c|c|c|c|c|c|c|c|c|c|c|c|c|c|}
\hline \multirow[t]{2}{*}{ Month } & \multirow[t]{2}{*}{$\mathrm{n}$} & \multicolumn{2}{|c|}{$\begin{array}{l}\text { Harpacticoid } \\
\text { copepods }\end{array}$} & \multicolumn{2}{|c|}{ Nematodes } & \multicolumn{2}{|c|}{$\begin{array}{l}\text { Crustacean } \\
\text { fragments }\end{array}$} & \multicolumn{2}{|c|}{$\begin{array}{l}\text { Copepod } \\
\text { nauplii }\end{array}$} & \multicolumn{2}{|c|}{ Hyalodiscus sp. } & \multicolumn{2}{|c|}{ Detritus } & \multicolumn{2}{|c|}{ Sand } \\
\hline & & $\% A$ & $\% F$ & $\% A$ & $\% F$ & $\% A$ & $\% F$ & $\% A$ & $\% F$ & $\% A$ & $\% F$ & $\% A$ & $\% F$ & $\% A$ & $\% F$ \\
\hline \multicolumn{16}{|l|}{1996} \\
\hline Jul & 1 & 100.0 & 100.0 & 0.0 & 0.0 & 0.0 & 0.0 & 0.0 & 0.0 & 0.0 & 0.0 & 0.0 & 0.0 & 0.0 & 0.0 \\
\hline Aug & - & - & - & - & - & - & - & - & - & - & - & - & - & - & - \\
\hline Sep & 3 & 50.0 & 33.3 & 50.0 & 66.7 & 0.0 & 0.0 & 0.0 & 0.0 & 0.0 & 0.0 & 0.0 & 0.0 & 0.0 & 0.0 \\
\hline Oct & 15 & 61.5 & 66.7 & 38.5 & 46.7 & 0.0 & 0.0 & 0.0 & 0.0 & 0.0 & 0.0 & 0.0 & 0.0 & 0.0 & 0.0 \\
\hline Nov & 12 & 25.1 & 58.3 & 37.8 & 41.7 & 0.0 & 0.0 & 36.8 & 58.3 & 0.3 & 8.3 & 0.0 & 0.0 & 0.0 & 0.0 \\
\hline Dec & 18 & 72.6 & 72.2 & 21.2 & 38.9 & 1.1 & 5.6 & 4.7 & 16.7 & 0.0 & 0.0 & 0.5 & 5.6 & 0.0 & 0.0 \\
\hline \multicolumn{16}{|l|}{1997} \\
\hline Jan & 14 & 79.9 & 78.6 & 17.5 & 28.6 & 0.0 & 0.0 & 2.5 & 35.7 & 0.0 & 0.0 & 0.0 & 0.0 & 0.0 & 0.0 \\
\hline Feb & 19 & 79.4 & 89.5 & 4.0 & 15.8 & 1.4 & 5.3 & 15.0 & 36.8 & 0.0 & 0.0 & 0.0 & 0.0 & 0.1 & 5.3 \\
\hline Mar & 20 & 80.8 & 80.0 & 1.9 & 10.0 & 1.1 & 10.0 & 11.5 & 20.0 & 0.0 & 0.0 & 4.3 & 5.0 & 0.5 & 20.0 \\
\hline Apr & 14 & 45.2 & 64.3 & 5.6 & 14.3 & 0.0 & 0.0 & 49.0 & 71.4 & 0.0 & 0.0 & 0.0 & 0.0 & 0.2 & 7.1 \\
\hline May & 15 & 97.7 & 100.0 & 1.8 & 6.7 & 0.0 & 0.0 & 0.4 & 13.3 & 0.0 & 0.0 & 0.0 & 0.0 & 0.0 & 0.0 \\
\hline Jun & 8 & 93.7 & 87.5 & 6.1 & 12.5 & 0.0 & 0.0 & 0.0 & 0.0 & 0.0 & 0.0 & 0.2 & 12.5 & 0.0 & 0.0 \\
\hline
\end{tabular}

There was significant variation in dietary composition throughout the year (for food items contributing $>3 \%$ of total abundance overall) among the 4 ontogenetic categories of $S$. trioostegitum (Table 9). In juveniles, the dietary composition varied with month, particularly from November to April (Fig. 3). Nematodes accounted for over $50 \%$ of total gut contents in November and January. The copepod nauplii contribution peaked in February and April. For males, harpacticoid copepods dominated in the winter and spring (except for the month of April). In November and April, the proportion of harpacticoid copepods decreased to less than $40 \%$ of total gut contents and the contribution by copepod nauplii increased to more than $40 \%$. In females, harpacticoid copepods were clearly the dominant food item throughout the year, except in October and November when more than $50 \%$ of total gut contents were composed of nematodes. In ovigerous females, the dietary composition varied from January to November, but the proportion of harpacticoid copepods remained high over this period.

\section{Gitanopsis japonica Hirayama 1983 (Amphilochidae)}

The most common food item in the gut of Gitanopsis japonica was detritus, which occurred in over $54 \%$ of the guts examined. Detritus constituted more than $32 \%$ of total gut contents (Fig. 1C). Harpacticoid copepods (mainly Parastenhelia sp.) were the second major food item. The other categories contributed only minor amounts to the diet $(<10 \%$ of total abundance each).

The relative composition of gut contents differed between the 4 ontogenetic categories of Gitanopsis japonica (Table 7). Detritus and harpacticoid copepods were the dominant food items in the guts of mature males and females. Nematodes represented $17.3 \%$ of the gut contents of females but only $5.4 \%$ in males. In the guts of ovigerous females, harpacticoid copepods were the dominant item. Polychaetes were the second major component, followed by detritus. There was no significant difference in the composition of gut contents between the 4 ontogenetic categories $\left(\chi^{2}=5.42\right.$,

Table 7. Gitanopsis japonica. Diet compositions in each ontogenetic category. \% A: percentage of abundance; \% F: frequency of occurrence; $\mathrm{n}$ : number of specimens examined

\begin{tabular}{|c|c|c|c|c|c|c|}
\hline \multirow[t]{2}{*}{ Food items } & \multicolumn{2}{|c|}{ Male $(\mathrm{n}=21)$} & \multicolumn{2}{|c|}{ Female (n = 15) } & \multicolumn{2}{|c|}{ Ovigerous female $(\mathrm{n}=32)$} \\
\hline & $\% A$ & $\% F$ & $\% A$ & $\% F$ & $\% A$ & $\% F$ \\
\hline Harpacticoid copepods & 16.2 & 9.5 & 23.0 & 13.3 & 24.0 & 18.8 \\
\hline Nematodes & 5.4 & 14.3 & 17.3 & 20.0 & 0.0 & 0.0 \\
\hline Crustacean fragments & 4.0 & 4.8 & 1.2 & 26.7 & 2.3 & 12.5 \\
\hline Polychaete juveniles & 0.0 & 0.0 & 0.0 & 0.0 & 22.0 & 18.8 \\
\hline Diatoms & 5.7 & 9.5 & 0.0 & 0.0 & 0.0 & 0.0 \\
\hline Detritus & 43.8 & 61.9 & 32.5 & 53.3 & 20.9 & 43.8 \\
\hline Sand & 3.3 & 47.6 & 5.8 & 40.0 & 1.3 & 31.3 \\
\hline Unidentified materials & 21.6 & 19.0 & 20.2 & 13.3 & 29.5 & 25.0 \\
\hline
\end{tabular}


Table 8. Gitanopsis japonica. Monthly variation of food items. \% A: percentage of abundance; \% F: frequency of occurrence; n: number of specimens examined; -: no data

\begin{tabular}{|c|c|c|c|c|c|c|c|c|c|c|c|c|c|c|c|c|c|}
\hline \multirow[t]{2}{*}{ Month } & \multirow[t]{2}{*}{$\mathrm{n}$} & \multicolumn{2}{|c|}{$\begin{array}{l}\text { Harpacticoid } \\
\text { copepods }\end{array}$} & \multicolumn{2}{|c|}{ Nematodes } & \multicolumn{2}{|c|}{$\begin{array}{l}\text { Crustacean } \\
\text { fragments }\end{array}$} & \multicolumn{2}{|c|}{ Polychaetes } & \multicolumn{2}{|c|}{ Diatoms } & \multicolumn{2}{|c|}{ Detritus } & \multicolumn{2}{|c|}{ Sand } & \multicolumn{2}{|c|}{$\begin{array}{l}\text { Unidentified } \\
\text { material }\end{array}$} \\
\hline & & & $\% F$ & $\% A$ & $\% F$ & $\% A$ & $\% F$ & $\% A$ & $\% F$ & $\% A$ & $\% F$ & $\% A$ & $\% F$ & $\% A$ & $\% F$ & $\% A$ & $\% F$ \\
\hline \multicolumn{18}{|l|}{1996} \\
\hline Jul & - & - & - & - & - & - & - & - & - & - & - & - & - & - & - & - & - \\
\hline Aug & - & - & - & - & - & - & - & - & - & - & - & - & - & - & - & - & - \\
\hline Sep & 2 & 0.0 & 0.0 & 0.0 & 0.0 & 24.8 & 50.0 & 0.0 & 0.0 & 0.0 & 0.0 & 74.4 & 100.0 & 0.8 & 50.0 & 0.0 & 0.0 \\
\hline Oct & 4 & 42.1 & 25.0 & 0.0 & 0.0 & 0.0 & 0.0 & 0.0 & 0.0 & 0.0 & 0.0 & 10.5 & 25.0 & 5.3 & 25.0 & 42.1 & 50.0 \\
\hline Nov & 1 & 0.0 & 0.0 & 0.0 & 0.0 & 0.0 & 0.0 & 0.0 & 0.0 & 0.0 & 0.0 & 0.0 & 0.0 & 0.0 & 0.0 & 100.0 & 100.0 \\
\hline Dec & 24 & 26.4 & 16.7 & 7.8 & 12.5 & 4.4 & 16.7 & 0.0 & 0.0 & 5.0 & 8.3 & 34.9 & 58.3 & 6.9 & 54.2 & 14.5 & 12.5 \\
\hline \multicolumn{18}{|l|}{1997} \\
\hline Jan & 2 & 50.0 & 50.0 & 50.0 & 50.0 & 0.0 & 0.0 & 0.0 & 0.0 & 0.0 & 0.0 & 0.0 & 0.0 & 0.0 & 0.0 & 0.0 & 0.0 \\
\hline Feb & - & - & - & - & - & - & - & - & - & - & - & - & - & - & - & - & - \\
\hline Mar & 1 & 0.0 & 0.0 & 0.0 & 0.0 & 0.0 & 0.0 & 0.0 & 0.0 & 0.0 & 0.0 & 0.0 & 0.0 & 0.0 & 0.0 & 100.0 & 100.0 \\
\hline Apr & 2 & 0.0 & 0.0 & 0.0 & 0.0 & 1.9 & 50.0 & 57.7 & 50.0 & 0.0 & 0.0 & 38.5 & 50.0 & 1.9 & 50.0 & 0.0 & 0.0 \\
\hline May & 6 & 0.0 & 0.0 & 2.9 & 16.7 & 0.0 & 0.0 & 12.9 & 16.7 & 0.0 & 0.0 & 20.6 & 50.0 & 0.3 & 16.7 & 63.3 & 50.0 \\
\hline Jun & 9 & 20.5 & 11.1 & 1.3 & 11.1 & 0.4 & 11.1 & 15.4 & 11.1 & 0.0 & 0.0 & 61.5 & 77.8 & 0.9 & 44.4 & 0.0 & 0.0 \\
\hline
\end{tabular}
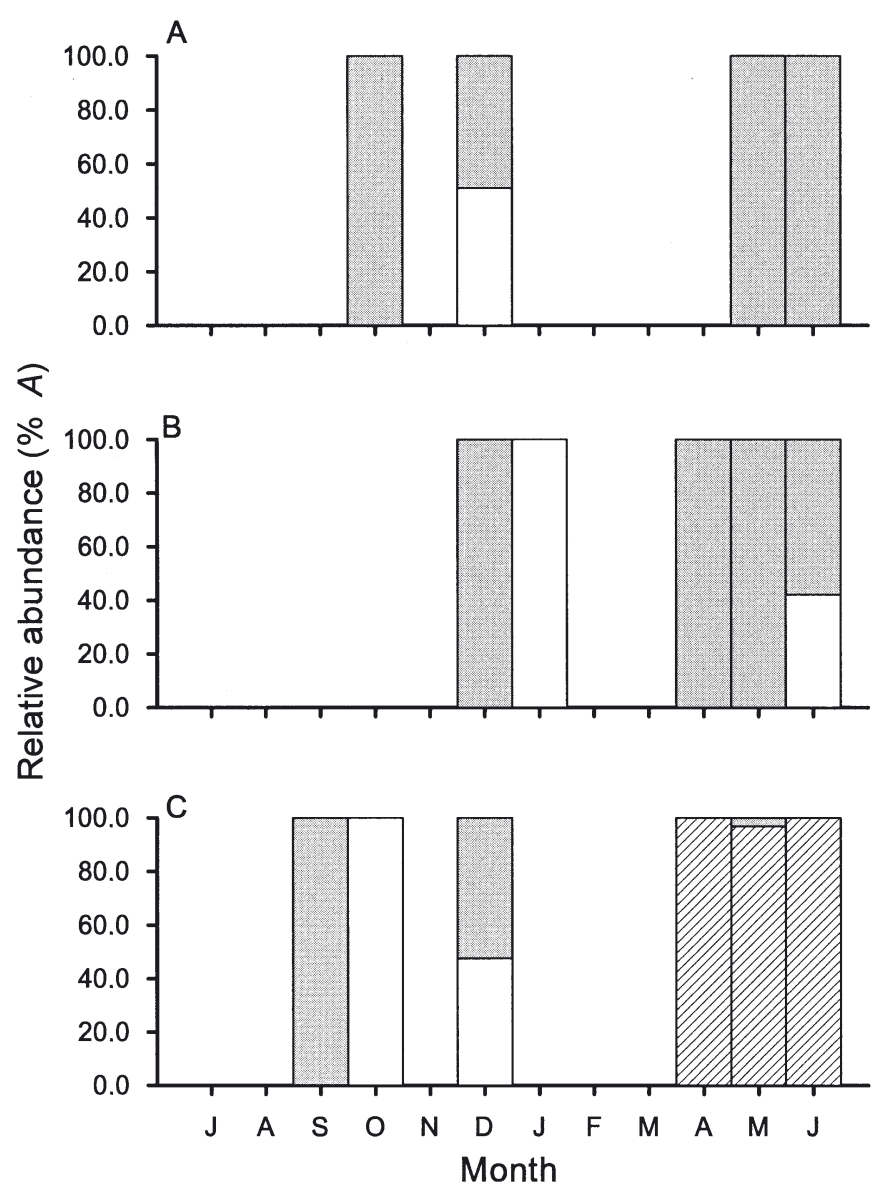

Harpacticoid copepods

QA Polychaeta juveniles

Detritus

Fig. 4. Monthly relative abundance $(\% A)$ of harpacticoid copepods, polychaete juveniles and detritus consumed by Gitanopsis japonica. (A) Males, (B) females, (C) ovigerous females $\mathrm{df}=10, \mathrm{p}>0.9)$. The overlap index between males and females was $90 \%$ (Table 3 ).

There was no variation throughout the year in the dietary composition of Gitanopsis japonica (Friedman test: $S=8.49$, df $=6, \mathrm{p}>0.1$ ). Harpacticoid copepods accounted for over $40 \%$ of total gut contents in October and January. In September, detritus and crustacean fragments were the dominant food items. Polychaetes were found in the guts after April (Table 8).

Differences in dietary composition fluctuated monthly (for food items contributing $>3 \%$ of total abundance overall) between the 4 ontogenetic categories of Gitanopsis japonica (Fig. 4). In males, the proportion of detritus continuously increased after December. In non-ovigerous females, harpacticoid copepods were clearly the main contributors to gut content in winter and spring, but accounted for less than $50 \%$ in other seasons. In ovigerous females, harpacticoid copepods occurred in October and December, whereas polychaetes accounted for over $50 \%$ of the total in April and June. However, these differences were not statistically significant for all ontogenetic stages (Table 9).

\section{Interspecific overlap indices of food items}

Overlap indices of gut contents were calculated for the 3 species (Table 10). An overlap index of $84 \%$ was found between Synchelidium lenorostralum and $S$. trioostegitum. There was little dietary overlap between S. lenorostralum and Gitanopsis japonica (49\%) or between $S$. trioostegitum and G. japonica (43\%).

Overlap indices of gut content composition were calculated between all ontogenetic categories of Synche- 
Table 9. Result of Friedman analysis $(S)$ of monthly variation of diet composition for each ontogenetic category of 3 amphipod species

\begin{tabular}{|c|c|c|c|}
\hline Species & $S$ & $\mathrm{df}$ & $\mathrm{p}$ \\
\hline \multicolumn{4}{|c|}{ Synchelidium lenorostralum } \\
\hline Juvenile & 15.77 & 6 & $<0.05$ \\
\hline Male & 29.72 & 6 & $<0.001$ \\
\hline Female & 42.28 & 6 & $<0.001$ \\
\hline Ovigerous female & 19.99 & 6 & $<0.05$ \\
\hline \multicolumn{4}{|c|}{ Synchelidium trioostegitum } \\
\hline Juvenile & 5.89 & 2 & $<0.05$ \\
\hline Male & 13.15 & 2 & $<0.001$ \\
\hline Female & 10.46 & 2 & $<0.005$ \\
\hline Ovigerous female & 5.52 & 2 & $>0.05$ \\
\hline \multicolumn{4}{|l|}{ Gitanopsis japonica } \\
\hline Male & 8.43 & 5 & $>0.05$ \\
\hline Female & 5.42 & 4 & $>0.05$ \\
\hline Ovigerous female & 2.73 & 4 & $>0.05$ \\
\hline
\end{tabular}

Table 10. Interspecific overlap indices of diets among Synchelidium lenorostralum, S. trioostegitum and Gitanopsis japon$i c a$, using the Schoener overlap index $(R o)$ and Spearman rank correlation $\left(\mathrm{R}_{\mathrm{S}}\right)$ (in parentheses). ${ }^{* * *} \mathrm{p}<0.001$

\begin{tabular}{|ll|}
\hline \multicolumn{1}{|c|}{ Species } & \multicolumn{1}{c|}{ Ro } \\
\hline S. lenorostralum vs S. trioostegitum & $84\left(0.937^{* * *}\right)$ \\
S. trioostegitum vs G. japonica & $43(-0.006)$ \\
S. lenorostralum vs G. japonica & $49(0.117)$ \\
\hline
\end{tabular}

lidium lenorostralum and $S$. trioostegitum (Table 11). The highest value $(90 \%)$ was found between nonovigerous females of $S$. lenorostralum and males of $S$. trioostegitum. The value of the index found between the juveniles, males and females of the 2 species was greater than $80 \%$; however, for ovigerous females of the 2 species, a value of $71 \%$ was found. The Spearman rank coefficients were not statistically significant for ovigerous females of $S$. lenorostralum, indicating a low similarity in diet compared with other developmental stages of the 2 Synchelidium species.

Table 11. Interspecific overlap indices of diets among Synchelidium lenorostralum and $S$. trioostegitum discrimination ontogenetic categories, using the Schoener overlap index $(R o)$ and Spearman rank correlation $\left(\mathrm{R}_{\mathrm{S}}\right)$ (in parentheses). ${ }^{*} \mathrm{p}<0.05,{ }^{* *} \mathrm{p}<0.01,{ }^{* * *} \mathrm{p}<0.001$

\begin{tabular}{|c|c|c|c|c|c|}
\hline & \multicolumn{4}{|c|}{ S. trioostegitum } \\
\hline & & Juvenile & Male & Female & Ovigerous female \\
\hline $\mathfrak{\Xi}$ & Juvenile & $81\left(0.717^{*}\right)$ & $79\left(0.660^{*}\right)$ & $75\left(0.885^{* * *}\right)$ & $82\left(0.882^{* * *}\right)$ \\
\hline Tี & Male & $74\left(0.699^{*}\right)$ & $83\left(0.642^{*}\right)$ & $88\left(0.902^{* * *}\right)$ & $81\left(0.966^{* * *}\right)$ \\
\hline 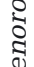 & $\begin{array}{l}\text { Female } \\
\text { Ovigerous }\end{array}$ & $66\left(0.778^{* *}\right)$ & $90\left(0.642^{*}\right)$ & $80\left(0.742^{*}\right)$ & $71\left(0.668^{*}\right)$ \\
\hline & female & $65(0.118)$ & $88(-0.009)$ & $79(0.340)$ & $71(0.315)$ \\
\hline
\end{tabular}

\section{DISCUSSION}

Amphipods fall into 7 major categories based on their feeding methods: suspension-feeders, surface detritivores, buried detritivores, scavengers, carnivores, commensals and grazers on living food (Biernbaum 1979). These feeding methods may differ between species, between habitats or seasonally within the same species. In this study, Synchelidium lenorostralum and $S$. trioostegitum were found to be carnivorous, preying mainly on harpacticoid copepods, while Gitanopsis japonica was mainly a surficial detritus feeder with some carnivorous behavior.

In this study, harpacticoid copepods were the dominant food item of both Synchelidium lenorostralum and $S$. trioostegitum. However, their importance as a dietary component varied with month and with ontogenetic stage (Figs. 2 \& 3). For example, Harpacticoid copepods accounted for over $95 \% A$ and $70 \% F$ of the dietary composition during the winter months, but a much lower proportion during other seasons. The seasonal variation in the composition of the diet may reflect, to some degree, the relative abundance and availability of the food item. According to Seon (2001), the abundance of Harpacticoid copepods at our study site was higher during winter than in other seasons. In contrast, for the gammarid Gammarus troglophilus, no seasonal changes in dietary composition were observed since the preferred food was present throughout the year (Jenio 1980). In another gammarid amphipod, G. fasciatus, the dietary composition is known to be related to the seasonal or temporal availability of food (Delong et al. 1993). Populations of G. fasciatus can persist in high numbers year-round because this species can take advantage of a range of food types (Summers et al. 1997). In the decapod crustacean Calocaris macandreae, variations in dietary composition were found to be related to changes in food abundance and availability within their benthic habitat (Pinn et al. 1998). The abundance of the 2 species of Synchelidium was higher during the winter and spring than in other seasons ( $\mathrm{Yu}$ 2001, Yu et al. 2002a). Moreover, the mean dry weights of the 2 species were highest during the winter (Yu 2001). Thus, the density of food items, such as harpacticoid copepods, may be an important factor accounting for variation in the dietary composition of benthic amphipods in sandy shore surf zones.

For Synchelidium lenorostralum, there was a significant difference in dietary composition with different ontogenetic stages (Table 2). This species displays 2 main recruitment 
phases during the year; in fall (October to December) and in spring (March to May) (Yu et al. 2002a). Juveniles of $S$. lenorostralum are dependent upon harpacticoid copepod nauplii and detritus as food sources at the beginning of breeding periods (Fig. 2). As juveniles developed to adults, the proportion of copepod nauplii in gut contents decreased and was lowest in ovigerous females. The ovigerous females of $S$. lenorostralum fed on whole bodies of adult benthic harpacticoid copepods. The reason for this ontogenetic shift in food use is unclear, but we propose 2 possibilities. First, the variation of food items may be related to ontogenetic changes in morphology. It is possible that juveniles of $S$. lenorostralum feed only on detritus and copepod nauplii because their mouthparts (or gnathopods) are unable to process larger food items. Second, the shift in diet may be related to reproductive effort. Large Synchelidium, especially ovigerous females, exclude smaller food items such as copepod nauplii and detritus. In Gammarus fasciatus, the growth rate is known to increase with size as a result of a progressive change to a more nutritious diet (Delong et al. 1993). Summers et al. (1997) suggested that an increasing size of food item along with increasing body size may lead to higher growth rates and earlier maturity. Studies have shown that when high and low quality diets were simultaneously offered to G. mucronatus and Elasmopus levis, both species fed preferentially on the high quality diet, resulting in faster growth and higher fecundity (Cruz-Rivera \& Hay 2000). Thus, the ontogenetic differences in the diet in S. lenorostralum, as observed in this study, may lead to faster growth rates and earlier reproduction.

The diets of Synchelidium lenorostralum and S. trioostegitum showed a high degree of overlap with each other, and a low degree of overlap with the diet of Gitanopsis japonica (Table 10). The large overlap in dietary composition may increase inter-specific competition for food, resulting in a low density of $S$. trioostegitum (Yu 2001). Also, food availability is an important factor influencing growth and productivity of a population (Poltermann 2000). The body size, brood size and egg size were greater in S. lenorostralum than in S. trioostegitum (Yu 2001), likely resulting from asymmetric competition for food. On the other hand, G. japonica was found to feed on a more varied diet, including items such as detritus, polychaete juveniles and harpacticoid copepods. G. japonica did not consume the same harpacticoid copepod species, which are the main food item of Synchelidium amphipods (Yu et al. 2002b). We suggest, therefore, that dietary differences lead to less competition for food between G. japonica and the 2 species of Synchelidium and that this favors coexistence.
Acknowledgements. We thank Dr. B. Sainte-Marie (Maurice Lamontagne Institute, Fisheries and Oceans Canada, Canada) and Dr. C.-W. Oh (Mokpo National University, South Korea) for critical reading of the manuscript and providing valuable comments. We also thank 4 referees for their valuable comments that improved the manuscript. This research was supported partially by a Korea Sea Grant Program of the Ministry of Maritime Affairs and Fisheries, Government of South Korea, and Grant-in-Aid for Scientific Research (no. 12NP0201).

\section{LITERATURE CITED}

Beare DJ, Moore PG (1997) The contribution of Amphipoda to the diet of certain inshore fish species in Kames Bay, Millport. J Mar Biol Assoc UK 77:907-910

Biernbaum CK (1979) Influence of sedimentary factors on the distribution of benthic amphipods of Fishers Island Sound. J Exp Mar Biol Ecol 38:201-223

Brown AC, McLachlan A (1990) Ecology of sandy shores. Elsevier, Amsterdam

Carrasco FD, Arcos DF (1984) Life history and production of a cold-temperate population of the sublittoral amphipod Ampelisca araucana. Mar Ecol Prog Ser 14:245-252

Cruz-Rivera E, Hay ME (2000) Can quantity replace quality? Food choice, compensatory feeding, and fitness of marine mesograzers. Ecology 81:201-219

Delong MD, Summers RB, Thorp JH (1993) Influence of food type on the growth of riverin amphipod, Gammarus fasciatus. Can J Fish Aquat Sci 50:1891-1896

De Troch M, Mees J, Wakwabi E (1998) Diets of abundant fishes from beach seine catches in seagrass beds of a tropical bay (Gazi Bay, Kenya). Belg J Zool 128:135-154

Dittmann S (2000) Zonation of benthic communities in a tropical tidal flat of north-east Australia. J Sea Res 43:33-51

Donn TE Jr, Croker RA (1986) Life-history patterns of Haustorius canadensis (Crustacean: Amphipoda) in northern New England. Can J Zool 64:99-104

Edgar GJ, Shaw C (1995) The production and trophic ecology of shallow-water fish assemblages in southern Australia. II. Diets of fishes and trophic relationships between fishes and benthos at Western Port, Victoria. J Exp Mar Biol Ecol 194:83-106

Fenchel T, Kofoed LH, Lappalainen A (1975) Particle sizeselection of two deposit feeders: the amphipod Corophium volutator and the prosobranch Hydrobia ulvae. Mar Biol 30:119-128

Gee JHR (1988) Population dynamics and morphometrics of Gammarus pulex L.: evidence of seasonal food limitation in a freshwater detritivore. Freshw Biol 19:333-343

Gerdol V, Hughes RG (1994) Feeding behaviour and diet of Corophium volutator in an estuary in southeastern England. Mar Ecol Prog Ser 114:103-108

Harvey CJ (1998) Use of sandy beach habitat by Fundulus majalis, a surf-zone fish. Mar Ecol Prog Ser 164:307-310

Icely JD, Nott JA (1985) Feeding and digestion in Corophium volutator (Crustacea: Amphipoda). Mar Biol 89:183-195

Ingolfsson A, Agnarsson I (1999) Anonyx sarsi: a major unrecognized scavenger and predator in the intertidal zone. J Mar Biol Assoc UK 79:1127-1128

Jenio F (1980) The life cycle and ecology of Gammarus troglophilus Hubrisht and Mackin. Crustaceana Suppl 6: 204-215

Johnson RK, Wiederholm T (1989) Long-term growth oscillations of Pontoporeia affinis Lindström (Crustacea: Amphipoda) in Lake Mälaren. Hydrobiologia 175:183-194 
Kline JL, Wood BM (1996) Food habits and diet selectivity of the brown bullhead. J Freshw Ecol 11:145-151

MacNeil C, Dick JTA, Elwood RW (1999) The dynamics of predation on Gammarus spp. (Crustacea: Amphipoda). Biol Rev 74:375-395

McLachlan A (1983) Sand beach ecology-a review. In: McLachlan A, Erasmus T (eds) Sandy beaches as ecosystems. Junk, The Hague, p 321-380

Nielsen MV, Kofoed LH (1982) Selective feeding and epipsammic browsing by the deposit-feeding amphipod Corophium volutator. Mar Ecol Prog Ser 10:81-88

Ojeda FP, Dearborn JH (1991) Feeding ecology of benthic mobile predators: experimental analysis of their influence in rocky subtidal communities of the Gulf of Maine. J Exp Mar Biol Ecol 149:13-44

Oh CW, Hartnoll RG, Nash RDM (2001) Feeding ecology of the common shrimp Crangon crangon in Port Erin Bay, Isle of Man, Irish Sea. Mar Ecol Prog Ser 214:211-223

Pinn EH, Atkinson RJA, Rogerson A (1998) The diet of two mud-shrimps, Calocaris macandreae and Upogebia stellata (Crustacea: Decapoda: Thalassinidea). Ophelia 48:211-223

Pöckl M (1995) Laboratory studies on growth, feeding, moulting and mortality in the freshwater amphipods Gammarus fossarum and G. roeseli. Arch Hydrobiol 134:223-253

Poltermann M (2000) Growth, production and productivity of the Arctic sympagic amphipod Gammarus wilkitzkii. Mar Ecol Prog Ser 193:109-116

Ross ST, McMichael RH Jr, Ruple DL (1987) Seasonal and diel variation in the standing crop of fishes and macroinvertebrates from a Gulf of Mexico surf zone. Estuar Coast Shelf Sci 25:391-412

Sainte-Marie B (1986) Effect of bait size and sampling time on the attraction of the lysianassid amphipods Anonyx sarsi Steele and Brunel and Orchomenella pinguis (Boeck). J Exp Mar Biol Ecol 99:63-77

Schlacher TA, Wooldridge TH (1996) Patterns of selective predation by juvenile, benthivorous fish on estuarine macrofauna. Mar Biol 125:241-247

Schoener TW (1970) Nonsynchronous spatial overlap of lizards

Editorial responsibility: Otto Kinne (Editor)

Oldendorf/Luhe, Germany in patchy habitats. Ecology 51:408-418

Seon SK (2001) Taxonomy and ecology of harpacticoid copepods in the intertidal zone of sandy shore, southern Korea. MSc thesis, Chonnam National University, Gwangju, p 1-78

Stuart V, Head EJH, Mann KH (1985) Seasonal changes in the digestive enzyme levels of the amphipod Corophium volutator (Pallas) in relation to diet. J Exp Mar Biol Ecol 88:243-256

Summers RB, Delong MD, Thorp JH (1997) Ontogenetic and temporal shifts in the diet of the amphipod Gammarus fasciatus in the Ohio River. Am Midl Nat 137: 329-336

Takahashi K, Kawaguchi K (1998) Diet and feeding rhythm of the sand-burrowing mysids Archaeomysis kokuboi and A. japonica in Otsuchi Bay, northeastern Japan. Mar Ecol Prog Ser 162:191-199

Takahashi K, Hirose T, Kawaguchi K (1999) The importance of intertidal sand-burrowing peracarid crustaceans as prey for fish in the surf-zone of a sandy beach in Otsuchi Bay, northeastern Japan. Fish Sci 65:856-864

Wear RG, Haddon M (1987) Natural diet of the crab Ovalipes catharus (Crustacea, Portunidae) around central and northern New Zealand. Mar Ecol Prog Ser 35:39-49

Wijnsma G, Wolff WJ, Meijboom A, Duiven P, de Vlas J (1999) Species richness and distribution of benthic tidal flat fauna of the Banc d'Arguin, Mauritania. Oceanol Acta 22: 233-243

$\mathrm{Yu} \mathrm{OH}$ (2001) Population ecology and production of the benthic amphipods (Crustacea) in a temperate sandy shore, southern Korea. PhD thesis, Chonnam National University, Gwangju, p 1-136

$\mathrm{Yu} \mathrm{OH}$, Soh HY, Suh HL (2002a) Life history and reproduction of Synchelidium lenorostralum (Amphipoda, Oedicerotidae) in a temperate sandy shore, southern Korea. J Crustac Biol 22:126-134

Yu OH, Soh HY, Suh HL (2002b) Seasonal zonation patterns of benthic amphipods in a sandy shore surf zone of Korea. J Crustac Biol 22:459-466

Submitted: April 17, 2003; Accepted: June 17, 2003

Proofs received from author(s): August 12, 2003 